\title{
Model Analysis of Political Message Processing of Prabowo-Hatta and Jokowi-JK in the Indonesian Presidential Election 2014 in West Jakarta
}

\author{
Analisis Model Pemprosesan Pesan Politik Prabowo-Hatta dan \\ Jokowi-JK dalam Pilpres 2014 di Jakarta Barat
}

\author{
Abdul Rahman HI \\ Universitas Mercu Buana Jakarta, Jl. Meruya Selatan DKI Jakarta \\ Drs.a.rahman.hi@gmail.com
}

\begin{abstract}
This research analyzed the political message processing of the voters of Prabowo-Hatta and Jokowi-JK in the Presidential Election 2014 in West Jakarta. The aim was to determine the influence of systematic and heuristic political message processing in the decision of beginner voters. Also, it targeted the political message processing model in the Presidential Election 2014. Quantitative research was used by conducting a survey and heuristic-systematic model was picked as the theory. It was derived into three variables, namely heuristic process variable, systematic process variable, and decision to choose president variable,. The result showed that the decision to vote Prabowo-Hatta was influenced more by systematic than heuristic political messages. On the other hand, the decision to elect Jokowi-JK was influenced more by heuristic than systematic political messages. If Prabowo-Hatta wished to improve their voters, they could strengthen the heuristic political message (emotional message), while for Jokowi / JK, they could strengthen the systematic political message (rational message).
\end{abstract}

Keywords: Decision of Beginner Voters; Heuristic Process; Presidential Election 2014; Systematic Process

\begin{abstract}
Abstrak
Judul penelitian ini yaitu analisis model pemprosesan pesan politik Prabowo-Hatta dan Jokowi-JK dalam Pilpres 2014 di Jakarta Barat. Penelitian ini bertujuan untuk menganalisa sejauh mana pengaruh pemprosesan pesan politik secara sistematik dan heuristik terhadap keputusan pemilih pemula dan model pemprosesan pesan politik pada Pilpres 2014. Metode penelitian yaitu kuantitatif dengan melakukan survei. Teori yang digunakan yaitu Heuristicsystematic model diturunkan menjadi variabel heuristik proses, variabel sistematik proses dan variabel keputusan memilih presiden. Hasil penelitian menunjukkan bahwa keputusan memilih Prabowo/Hatta lebih dipengaruhi oleh pesan politik sistematik dibandingkan heuristik, sebaliknya keputusan memilih Jokowi/JK lebih dipengaruhi pesan politik heuristik dibandingkan sistematik. Jika pasangan Prabowo/Hatta ingin meningkatkan keputusan memilihnya, maka harus memeperkuat pesan politik secara heuristik (pesan emosional). Jika pasangan Jokowi/JK ingin meningkatkan keputusan memilihnya, maka harus memperkuat pesan politik yang sifatnya sistematik (pesan rasional).
\end{abstract}

Kata Kunci: Keputusan Pemilih Pemula; Pilpres 2014; Proses Heuristik; Sistematik Proses 


\section{Introduction}

Philosophical discourse concerning people's power and sovereignty plays a significant role in giving birth to thoughts regarding forms of government. Throughout the history of humankind, those ideals are attempted to be implemented, and, to some extent, the process is responsible for enabling the manifold of current systems of government. The constitution is an example of a holistic method applied to manage and conserve the relation between people's sovereignty, government, and statehood born from history.

Typically, a country runs systems of government, such as monarchy, communism, liberalism, presidentialism, parliamentarism, or democracy, and the derivations by considering the will and historical process of the country. Systems of government as a united and holistic entity containing basic rules are ratified in the constitution, and it rules systems of government and statehood. In Indonesia, the pattern of the government and administration adopts democracy, including the elections of legislative and executive and the process of policy-making. It is the reason that people's sovereignty in Indonesia is carried out on elections, and a direct presidential election, then, as one of the processes of the politics of democracy, is entrenched the best option available to elect the persons that wield the executive power of governmental policies.

Indonesian presidential election is not only a political process to elect the leader of the nation but also to vote the values, political ideas, interests, and political program that can develop the country. The elected president will decide the official ministers and other opportunities to help them formulate and enact public policies for five years. However, although the elected officials are the institution that realizes people's mandate, the mandate itself is still attached to the people through participation.

Typically, when it comes to democracy, many scientists refer back to Aristotle, de Tocqueville, and Schumpeter. As regards Aristotle, he divided the form of government into six, royalty, tyranny, aristocracy, oligarchy, polity, and democracy. This classification provided ideas, conception, and ideology for many countries to be established (Cunningham, 2002:7). Different from Aristotle, de Tocqueville was in favor of more of the equality of the people. This value of equality then is considered one of the pillars of the next theories, including theories of people's political rights that affirm that each citizen has a right to elect and be elected. Indeed, the recent theories have expanded that right to not only in the ballot of the election but also for a public position, economic equality, and cultural diversity (Tocqueville, 1969:60). Another essential conception is from Schumpeter that saw democracy as a function to delegate individuals as the policymakers through people's voices. Besides, other thinkers also contributed to enriching this discourse, ranging from Jean-Jacques Rousseau, James Madison, Immanuel Kant, to John Stuart Mill (Schumpeter, 2003:10).

The word democracy itself stems from Greek words, "demos" and "kratos," which means a form of government originating from the people. It can also mean a government elected by the representative. Apart from that, democracy inherently implies that the highest authority is in people's will. Democracy is meant to grow public participation and not only individuals or groups. The public in this system owns a significant role since it highly figures in deciding the public interest. For example, in democratic countries, the requirement for appointing the village leader, mayor, governor, and president, is the approval of the people, whether directly or indirectly (Irawan, 2018:91).

However, the philosophical basis of the ideas, values, and conception of democracy, instead of determined by the characteristic of democracy and the quality of 
the application in the empirical world, is typically influenced more by the existing institution and democratic values. Therefore, democracy should be defined by the application of the idea of justice and freedom. It is in agreement with what is stated by Cunningham (2002:3) that normative values of democracy should be based on equality before the law, equality of voice (or one person, one vote, one weight), liberty, freedom, pluralism, tolerance, solidarity and human rights.

The normative value of democracy states that public participation is necessary for supporting the system. This understanding is in line with Christian Wulff that stated that democracy is closely linked with public participation. Owing to ethical and practical considerations, democracy is deemed an accurate way to involve the public in deciding the making process and transform the situation. Each person has the right to vote in the process and management of development (Scholte, 2014: 3). With the same spirit, Mazzuca and Munck (2014) asserted that democracy offers a solution to solve problems related to the country (Wang dan Yiqing, 2018: 1).

Democratic normative value has been studied and criticized; making normative values of democracy seems broader than the democracy of politic itself. Consider equality as an example; equality is not only about equality to be elected and to elect anymore but also equality in accessing government service, opportunity, welfare, and happiness. According to Hyland (1995:63-64), it can be tracked in the conception of antique Greek. Once a motion was put to the assembly, every citizen had the right to address the people. This was known as Isegoria, or equality of voice. For the Athenians, this equal right to voice one's opinions was one of the central elements of their "demokratia." The first point to be made about the free and open debate is that it is a central and efficient way of ensuring equal access to relevant information; in simple matters, each decision-maker might be fully informed on all relevant matters before die decision-making.

Hayek, in Hylan (1995:106), rejects the proposed means, namely state action. He rejected those means because he believed that extending the scope of collective authoritative decision-making into the area of the provision of these positive conditions of empowerment will be inefficient, democratically counter-productive and, finally, subversive of the fundamental value that democracy itself is meant to serve, namely, the value of individual liberty. Democratic values are not idealistic utopia and it lives in the empirical structure of daily lives. Hayek considers equality in the law enforcement of society. It is not surprising then if there is a caveat that says that the public is placed highly in the election, but their social concerns are ignored at the practical level where the government executes their program.

The philosophical thought of systems of government adhered by a country develops from time to time. How much portion of values applied make the characteristic of the system government and politics? It affects which form that a country will tend to, whether they will choose liberal democracy, representative democracy, or participatory democracy (Cunningham, 2002:1) Substantially, the presidential election will determine which values will be performed in the government and countries politic. Values developed in the political ideas and group of interest of the political party will be associated with control of natural resources, not only for cabinet members but also for the government direction for the next five years.

Indonesian presidential election 2014 was conducted on July 9, 2014. The candidates were Prabowo Subianto-Hatta Rajasa and Joko Widodo-Jusuf Kalla. To gather public support, the candidates, together with the coalition parties, performed 
communication politics in the form of political messages. They aimed to increase the popularity and electability of the candidates, the dissemination of party programs and values attempted, as well as the distribution of political choice during the election.

A mature democracy system could be manifested if there is high public participation. All citizens that have met the constitutional requirements should also give their votes in the elections. In this condition, each citizen, without recognizing the social hierarchy of the person, has the same right to choose and be chosen. Through this system, each citizen has the same right and opportunity to decide the future of the nation every five years. However, the younger generation's participation in politics is always debatable. The reason is that many younger generations are considered apathetic towards politics.

The younger generation is often deemed as a group that is apathetic towards politics, separated from their community, skeptical about political processes and problems, and cynical towards any political and government institutions. Also, they are generally seen as a group that has a low level of political trust (Haste \& Hogan, 2006). Data showed that younger people involved in the political party are still rare, and mostly they are absent in the election (EACEA, 2012), although their roles in elections are fundamental for a better system of democracy.

The functions of political parties in the democratic country are conducting political education, being the political communicator, and performing both top-down communication through formal processes and bottom-up communication through feedbacks from the constituents. Every constituent should be attracted so that the political party could obtain a high proportion of national votes and wield power.

Attempts to gain power through democracy is founded on the participation of all mature citizen. People's opinion and the choice is conducted directly and indirectly, and the government institutionalizes it. Public political preference will legitimate political power in determining the nation's direction. The election gains the majority decision of democracy.

Democratic processes call for communication skills, ranging from communication regarding the candidate, parties' vision, dynamics in the coalitions of the party, work program to anything necessary to deliver to the constituents. Indonesian general election commission needs sequences and processes to communicate the Indonesian presidential election to the organizers and the society. Knowledge and awareness of the voters will determine the quality of the elections. Therefore, the intersection between democracy and politic is that democracy is a sphere for the development and advancement of political communication.

Political communication, according to Mulyana (Husain, 2011:211), study chains of communication and politic or methodological bridge between communication and politics. Indeed, political communication, together with other divisions, such as information systems, interpersonal communication, mass communication, organization communication, inter-cultural communication, instructional communication, and health communication, has been recognized as a distinctive study by International Communication Association.

One of the ways attempted by political parties to gain support from the public is through campaign advertising. In 2014, the budget campaign for advertisement in television, printed media, and radio, can be seen through this passage:

The budget of two candidates, Joko Widodo-Jusuf Kalla dan Prabowo SubiantoHatta Rajasa, is predicted to reach 40 billion rupiahs for a month. According to 
Lembaga Satu Dunia, from 22 may to 23 June, the candidates have spent at least 38 billion rupiahs. That amount is elicited from 2.821 advertisements appearance observed from 25 television stations, 20 radio stations, 33 newspapers in five big cities in Indonesia. Jokowi-JK has advertised for 1.790 times while PrabowoHatta for 1031 advertisement. As a result, Jokowi-JK in total has spent Rp19.411.695.395, while Prabowo-Hatta has spent Rp19.174.758.988. (http://kabar24.bisnis.com)

Admittedly, in democratic activity, the campaign is the most necessary procedure to do to reach public trust. As stated by Gronbeck (1978) and Norris (1999) explained the campaign has several functions, including winning the war of ideas, transforming and mobilizing the supporters, disseminating claims, and topics of information. The campaign usually is exercised through communication channels mediated by Technology (Jensen, 2017:22).

In addition to campaign advertising, the message of political communication is disseminated through out-of-home advertising, new media, group communication, event campaign, and other similar forms. Every attempt that is performed by the presidential candidate and the political parties, together with opinion communicated, is accepted by the public as a political message. In perspective of sociopsychology, that message that is processed by the individual, whether heuristically and systematically, will affect their political decision.

Political message, whether through a face-to-face communication or mass media such as news, dialog, political advertising, advertorial, and other forms, is a message that sooner or later will be processed by the public. What kind of messages that should be made, how the process is processed, how to process available knowledge, how to process the same message with the same needs but different motive, how to choose message to be processed, how interpersonal relationship in society affect personal opinion, and how message procession eventually will determine political decision in 2014 presidential election. How persuasive messages, which in this case political message emphasizing audience involvement, cognitive process, and information processing channel are processed, can be explained using elaboration likelihood model (ELM) Petty and Cacioppo (1986), and heuristic-systematic model initiated by Chaiken, Liberman, and Eagly (1989).

Chaiken, Liberman, and Eagly (1989) argued that, on the one hand, the message is processed systematically if the receiver consciously, carefully, logically, and based on strong foundations, process the message before concluding. On the other hand, the message is processed heuristically if the receiver draws a conclusion without complete message, knowledge, and consideration. In other words, in an election case, the individual that chooses heuristic processing to decide their decision in an election merely takes a short time while those who picked systematic processing require a longer time and more information before deciding the elected. Systematic information processing is identical to the central route, while heuristic information processing is identical to peripheral processing in ELM.

The main theories or models of persuasive processing is information processing theory (McGuire 1968) and two models of dual-process models of information: elaborations likelihood model and heuristic-systematic model Chaiken, Liberman, and Eagly (1989). The heuristic-systematic model describes two ways of persuasive message 
processing, systemically and heuristically. Systematic processing reflects the careful, analytical, and serious observation of messages. The heuristic process is a means that is simpler by using rules or prediction schemes to appraise or make a decision.

According to Petty \& Cacioppo (1986b), which route is taken is a matter of motivation and cognitive capacity. If the speakers have followed the arguments, then the central path will be used. If so, then the arguments have to be put carefully as the speaker will pay attention to them. If arguments are sound, it will be changed based on the attitudes. If not, the peripheral route is used; much more superficial arguments can be used and found it around persuasion cues (attractiveness).

Although both systematic and heuristic information processing may create a memory that is quite durable, the former tend to be last longer and more permanent, as opposed to the latter. Similarly, it also happens in information processing that can strengthen resistance or recognition toward the political party and its attribution. Both systematic and heuristic information processing could affect the opinion, decision, consideration of voting the candidate.

In the previous research, Irawan (2018) showed that younger generations are often seen as a group of people that is apathetic with political issues, that often be separated from their communities, that is not interested in political process and issues, that have no political trust, and that is cynical towards political institution and the government (Pirie \& Worcester, 1998; Haste \& Hogan, 2006). This conception is often justified by data that shows that younger generations' participation in a political party is low. They even prefer not to vote during the election (EACEA, 2012) despite their essential significance for the development of democracy.

Considering the reality of younger generation participation that is reasonably low, whether according to the previous research and media coverage, this research chose young voters as the subject-matter. The remembered political message received by the young voters can make them describe attributes attached to the candidate. Political message that was processed well heuristically and systematically determine the understanding and behavior of young voters of 2014 presidential elections. Therefore, the research studied political message recalled a year after the election. West Jakarta was chosen as the location since, in addition to a region with the second largest population, the proportion of younger voters is $21 \%$.

Considering the proportion of young voters and that political message processing determine young voter decision, the research formulates two research question: firstly, how far the influence of political message processing towards young voter decision in presidential election 2014? Secondly, how is the model of political message processing of the voters of Prabowo-Hatta and Jokowi-JK in the 2014 presidential election? This research aims to describe, analyze, and explain: firstly, the influence of political message processing towards young voter decisions in presidential election 2014, and secondly, the model of political message processing of the voters of Prabowo-Hatta and Jokowi-JK in 2014 presidential election.

\section{Methodology}

The research exercised a survey, together with explanative research design, to collect clarity of causal connection between heuristic and systematic information processing and the decision of young voters to elect either Prabowo-Hatta or Jokowi JK. The data was collected with a questionnaire that uses a Likert scale with closed-ended questions. 
Young voter population in west Jakarta, according to KPU data by considering that total voters in west Jakarta was 1.661 .193 and young voters proportion was $14 \%$, the population in this research was 232.588 young voters. Using Taro Yamane calculation with a margin of error 5\%, a sample with 400 young voters was obtained. The sample was collected by multistage sampling (http://data.kpu.go.id/ss89.php).

The indicators for the variables of heuristic processing were: implicit and straightforward messages, low involvement and awareness, low-level of knowledge, low motivation, low processing capability. On the other hand, the indicators of the variables of systematic processing were: complex and explicit messages, complex response, high involvement and awareness, high level of knowledge, high motivation, high processing capability. The other variable was the decision to vote between Prabowo-Hatta or JokowiJK.

Path analysis was chosen to explain and analyze the causal connection that has been hypothesized. Ordinal data were converted to the interval with a multi successive interval. The core point of path analysis of the Sewall Wright principle is multivariate regression. Path analysis is more flexible in adapting with the analysis, recognizing the direct and indirect influence (from other variables), identifying total influence, and the influence of other variables that are not included in the model (epsilon) but significant for the dependent variables. The diagram below is the stages in the path analysis, according to Wright (1934) in Al rasyid (1998: 7-10), of the research:

Figure 1. Relation between variable

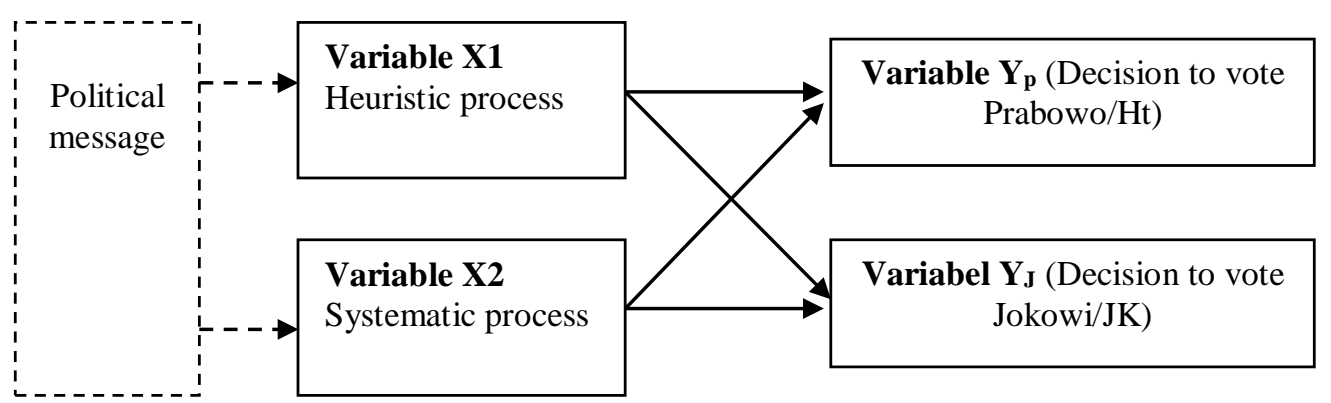

A message with high motivation, high-level of argument, especially that come from credible sources, were processed through the systematic line. The ambiguous and illogical message, with low motivation in seeking other sources as the supplement of political message, on the other hand, was processed through the heuristic line.

\section{Results and Discussion}

The influence of the heuristic process toward the decision to vote Prabowo-Hatta was $2,67 \%$, and the influence of systematic process towards the same candidate was $12,62 \%$. Influences of all variables of systematic and heuristic information processing towards the decision to vote Prabowo-Hata was $15,29 \%$. 
Figure 2. Heuristic and systematic process towards Prabowo-Hatta's voters

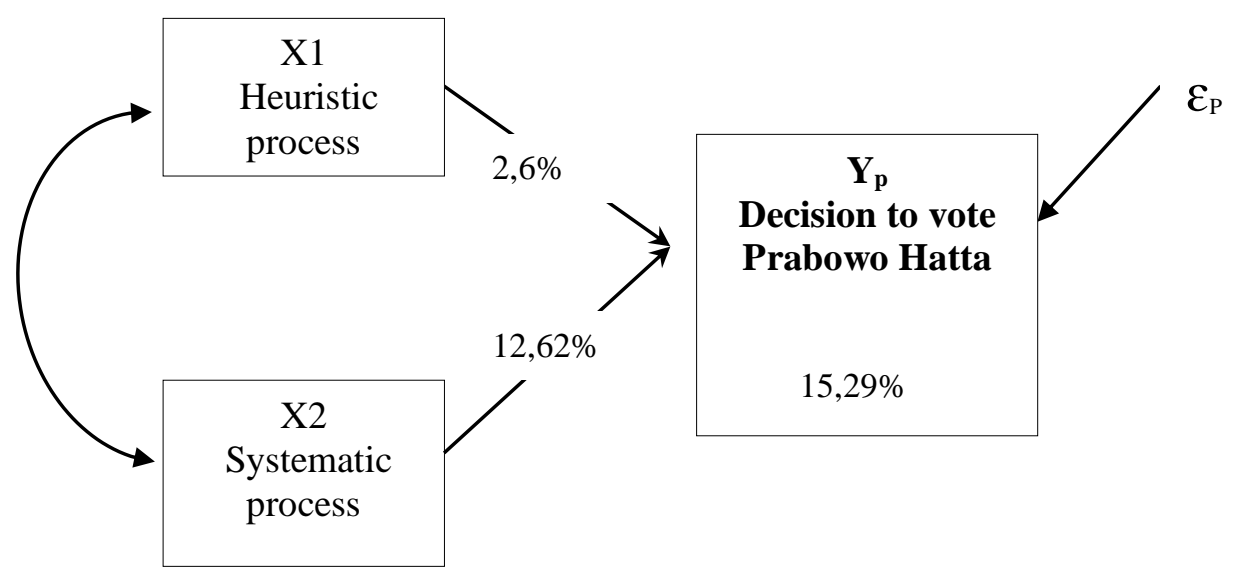

Prabowo's voters processing systematic political message was more significant than heuristic one. Based on the heuristic-systematic model Eagly and Chaiken, Prabowo's voters processed information more on the political message that is logical, explicit, with definitive evidence and data, and high awareness. In other words, they were more rational voters than voters that process information heuristically or traditionally. The heuristic message that was received without further consideration was implicit, illogical, low in the motivation to seek further information was not influential in this group.

Unlike Prabowo-Hatta, the influence of the heuristic process toward the decision to vote Jokowi-JK was $12,04 \%$, and the influence of systematic process towards the same candidate was $4,63 \%$. Influences of all variables of systematic and heuristic information processing towards the decision to vote Jokowi-JK was $16,67 \%$.

Diagram 2. Heuristic and systematic process towards Jokowi-JK's voters

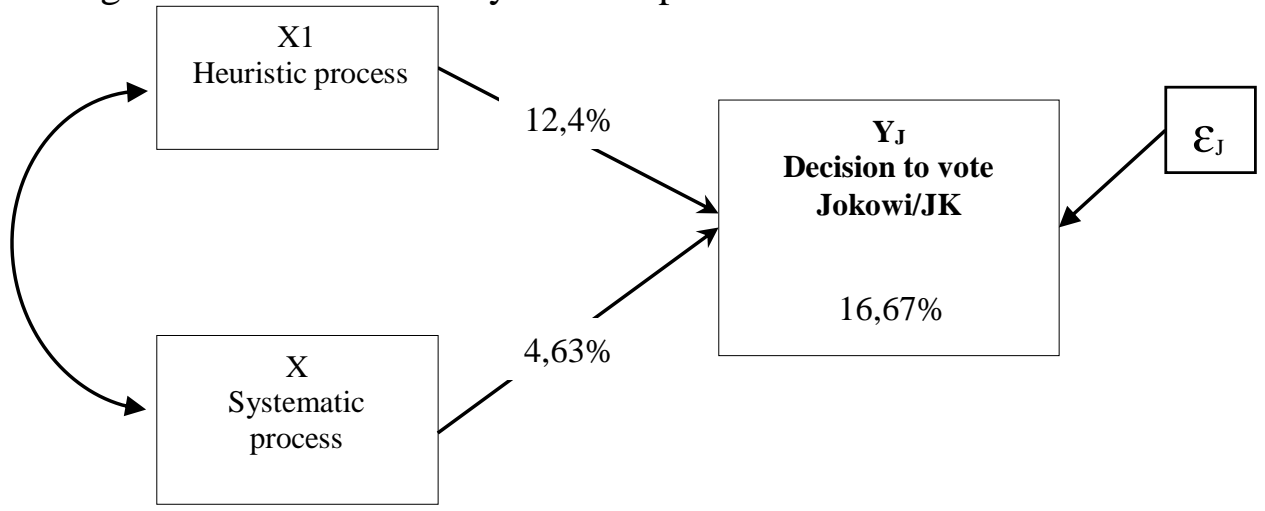

Heuristic-Systematic Model Eagly and Chaiken's (1993) in Steenbergen (2011:45) One of the most prominent dual-process theories is the heuristic-systematic model developed by Chaiken and her colleagues (Chaiken, 1980, 1987; Chaiken, Liberman and Eagly, 1989; Chen and Chaiken, 1999). Here, systematic processing refers to the systematic use of decision-relevant information. When in systematic processing mode, individuals absorb and take heed of the decision-relevant information that is currently available, heuristic processing requires much less effort. Here, the decision-maker applies a set of judgmental rules often in the form of standing decisions if that operates independently and in insulation from the information environment. 
Jokowi's voters' that processed heuristic political message was more significant than the systematic one. Based on the heuristic-systematic model Eagly and Chaiken, Jokowi's voters processed information without further consideration, and that was more implicit, illogical, low in motivation in seeking information on the political message. On the other hand, political message that was logical, argumentative, explicit, with conclusive evidence and data, high awareness, elicited with a sufficient amount of time, was less significant on Jokowi's voters.

It can be concluded that the decision of Prabovo's voter was influenced more by systematic political message while Jokowi's voter was determined more by heuristic message processing. Systematic and heuristic message processing in Prabowo-Hatta was $15,29 \%$, and Jokowi was $16,67 \%$. The gap then was $1,38 \%$. Prabowo, to increase the supporters, could improve heuristic political message or by inviting more traditional voters, while Jokowi-JK could do the inverse, by improving the number of systematic political message or rational voters.

Attitude and behaviors of young voters were determined by many factors, ranging from private sources to mass media. For Prawbo-Hatta, they chose them because of 10 reasons, namely because he was firm, accountable, capable, competent, convincing, confident, track record, work program, energetic, charismatic, from military, having character, and ambitious. Jokowi-Jk, on the other hand, was chosen because they were humble, modest, capable, honest, convincing, confident, and track record. Also, they liked to visit and meet people, as well as have an appropriate work program.

Many personal and social needs of young voters were satisfied by social media use. The internet diet affected the heuristic process of the candidate. The younger voters' reception towards candidates with a process that was not complex, inference process that was not deep, fast, and acquired without complete data originated from candidates' attributes gain from the fulfillment of the needs.

Systematic information processing was not determined solely by the fulfillment of the need for candidate information from mass media but also from the audience's agenda. Audience agenda setting was a logical attempt to opt the type of the media, including the content, and the level of awareness to the candidate determined attention to mass media.

The attitude of the voters was conditioned by the source used to fulfill the needs towards who and what the agenda of the coalition of the parties. It was located in the variation of curiosity, together with cognition, affection, social, and entertainment needs to be obtained from the political advertising campaign about the candidates and the supporting parties.

According to young voters, sources of the opinion and satisfaction of the mass media use towards information processing, whether heuristically or systematically, of Prabowo-Hatta was more significant than of Jokowi-JK However, voters' behavior of Jokowi-JK was more significant than Prabowo-Hatta. This is because the voters' behavior of Jokowi-JK was conditioned more by heuristic and systematic process while the systematic process determined Prabowo-Hatta's voters.

\section{Conclusion}

The research has found that the decisions of Prabowo-Hattas's voters were more determined by the systematic political message than the heuristic one. The decisions of Jokowi-Kalla's voters were more determined by the heuristic political message than the 
systematic one. The influence of both heuristic and systematic political messages towards decisions to vote Jokowi-JK was more significant than Prabowo-Hatta. The gap in the influence of political message towards decisions' voters was relatively small. Consequently, to increase the number of voters, Prabowo Hatta could produce a more heuristic political message while for Jokowi-JK by producing more systematic political messages.

\section{Acknowledgment}

The researcher thanks Prof. Dr. Harsono Suward, MA, and Dr. Udi Rusadi M.Si as the researcher's promotor and co-promotor, respectively, that have supervised and directed the researcher in the research.

\section{References}

Al Rasyid, Harun. (1994). Analisis Jalur (Path Analysis). Dalam K Sitepu (penyunting), Path Analysis, Bandung: Unit Pelayanan Statistika FMIPA Universitas Padjadjaran

Chen, Serena Kimberly Duckworth, Shelly Chaiken. (1999). Motivated Heuristic and Systematic Processing. Psycological Inquiry, 10(1) pp. 44-49.

Cunningham, Frank (2002). Theories of Democracy A critical introduction. Routledge 11 New Fetter Lane: London.

Haste, H. \& Hogan, A. (2006). Beyond conventional civic participation, beyond the moralpolitical divide: Young people and contemporary debates about citizenship. Journal of Moral Education, 35(4), 473-493.

Husain, M. N. (2011). Penerapan Komunikasi Politik dalam Penetapan Peraturan Daerah Kota Kendari. Jurnal ASPIKOM, 1(3), 211-222.

Hyland, James L. (1995). Democratic theory: the philosophical foundations. University Press Oxford Road: New York.

Irawan, E. P. (2018). The Dynamic of the Role of Volunteer as a Political Communicator: A Descriptive Study on Volunteer's Agus-Sylvi at the Election of the Jakarta Governor 2017. Asian Journal of Humanities and Social Studies.

Jensen J Michael. (2017). Social Media and Political Campaigning: Changing Terms of Engagement?. The International Journal of Press/Politics, 22(1) 23-42.

Scholte, Aart Jan. (2014). Reinventing Global Democracy. European Journal of International Relations 2014, 20(1) 3-28. University of Warwick, UK.

Schumpeter,A.Joseph. (2003). Capitalism, Socialism And Democracy, This edition published in the Taylor \& Francis e-Library. Routlegge, London and New York

Steenbergen, R.Marco, Hangartner Dominik, de Vries E. Catherine. (2011). Choice under Complexity: A Heuristic-Systematic Model of Electoral Behavior, Paper prepared for the Annual Meeting of the Midwest Political Science Association, Chicago.

Wang Erik H. dan Yiqing Xu. (2018). Awakening Leviathan: The Effect of Democracy On State Capacity. Research \& Politics, 5(2), pp. 1-7. 